\title{
Theme-Rheme Configuration in Recount Texts Produced by Indonesian EFL Students
}

\author{
Kiki Meiarista, Widhiyanto ${ }^{\bowtie}$
}

English Department, Faculty of Languages and Arts, Universitas Negeri Semarang, Indonesia

\begin{abstract}
Article Info
Article History:

Received in 3

February 2020

Approved in 13 July

2020

Published in 30 July

2020

Keywords: Textual Meaning; Thematic Structure; Thematic Development Pattern; The Problem of Thematic Development; Recount Text

Abstract

The topic of this study is the textual meaning in recount texts written by the fourth semester students of English Department Universitas Negeri Semarang in the academic year 2018/2019. This study is conducted since there are still limited research that is conducted in Indonesia which analyses the problems of thematic development because most of Indonesian researchers are only analyses the thematic structure and thematic development pattern. This study aimed to figure out the thematic structure, thematic development pattern, and the problems of thematic development in students' recount texts. The text analysis of qualitative method was employed to enhance the results. The result of the thematic structures showed that the unmarked topical Theme was frequently used than the marked one in terms of topical Theme, the conjunctions became the mostly used element in textual Theme, and the modal adjuncts became the frequently used constituent in interpersonal Theme. In the case of thematic development patterns, the Theme re-iteration (constant Theme pattern) became the mostly used pattern since the function is to keep the text focused. It has been found that there were three problems of thematic development in students' recount texts: (1) the problem of the brand-new Theme, (2) the problem of double Rheme, and (3) the problem of empty Rheme. The results of this study indicate that the students belong to beginner (inexperienced) writer.
\end{abstract}

(C) 2020 Universitas Negeri Semarang

\footnotetext{
Correspondent Address:

B3 Building FBS Unnes

Sekaran, Gunungpati, Semarang, 50229

E-mail: kikimei96@gmail.com
}

p-ISSN 2252-6706 | e-ISSN 2721-4532 


\section{INTRODUCTION}

In learning language, people have to master the four main skills of language: listening, speaking, reading, and writing. Listening and reading are considered into receptive skills because people only receive information either through listening or reading. Whereas speaking and writing are considered into productive skills because people produce sounds in speaking and symbols in writing.

Writing is considered as a difficult task for English as a Foreign Language (EFL) students because of the complexity of the writing process. During the writing process, students need to organize ideas into a good sentence, then arrange sentence by sentence into a good paragraph, and link paragraphs into text. Students also need to pay attention on vocabulary, spelling, punctuation, grammar, cohesiveness, and coherence of a text in order to make the text is readable, acceptable, and meaningful. Most of the students find difficulties in starting 'what to write', generating ideas, choosing the proper words, and relating each clause into a cohesive and coherence text. It happens because they do not know about Theme and Rheme.

The students are not familiar or even do not know about the Systemic Functional Linguistics (SFL). SFL is a theory that is developed by M. A. K. Halliday in the 1960s. It focuses on the purposes and the uses of language as a system for making meaning. In SFL, meaning is divided into three: ideational/experiential, interpersonal, and textual. Textually, the clause contains a message; interpersonally, clause is seen as an exchange; and experientially, clause is seen as a representation. Ideational meaning is a meaning which construing human experience. Interpersonal meaning is a meaning that enacting personal and social relations, this meaning expresses attitudes and judgements. Textual meaning is a meaning which relates to the construction of a text. Those meanings are also called metafunction (Halliday \& Matthiessen, 2014, pp.30-31).

One of the meaning that is going to figure out in this study is textual meaning. The textual meaning is realized through the Theme and Rheme. Theme is the point of departure to guide the addressee in developing an interpretation of the message and Rheme is the part where the Theme is developed (Halliday \& Matthiessen, 2004, 2014). Theme is realized by initial position in the clause and Rheme follows (Martin, Matthiessen, \& Painter, 1997, p.21). In short, Theme is the beginning of the clause which contains the information and Rheme is the rest of the clause which contains new information.

The Theme elements are divided into three: ideational/topical Theme, interpersonal Theme, and textual Theme (Halliday \& Matthiessen, 2004, 2014). The ideational/topical Theme is the first constituent that is either participant, circumstance, or process. It is divided into two: marked and unmarked topical Theme. The unmarked topical Theme is Theme on to Subject, while the marked topical Theme is Theme other than Subject. The ideational/topical Theme occurs in all clauses although it might be ellipsis. The interpersonal Theme is an element that occurs before the topical Theme, includes modal/comment adjunct, vocative, and finite verbal operator. The textual Theme occurs before the interpersonal or topical Theme which relates the clause to its context. It includes continuative, conjunction, and conjunctive adjunct. The Theme which contains more than one element is called multiple Theme (Halliday \& Matthiessen, 2014, p.107).

The development from Theme to Rheme shows the flow of information. It is common to put an old information (the information from the previous sentence or clause) followed by a new information in order to maintain the cohesiveness and coherence of a text. There are three main patterns in developing a text: Theme reiteration, the zig-zag pattern, and multiple-Rheme pattern (Eggins, 2004, pp.324-325). In the Theme reiteration (constant Theme pattern), re-iterate an element is a way to keep the cohesiveness or the focus of a text. This pattern is found when the same element appears regularly in the beginning of the clause (Theme). The repetition of the same element of Theme provides a clear focus of the text. The zigzag/linear pattern occurs when the element that is introduced in the Rheme of the previous clause becomes the Theme of the next clause. In this pattern, the cohesiveness of a text is achieved by building on the newly introduced information. The last pattern is multiple-Rheme pattern. In this pattern, the Rheme of the previous clause is divided into a number of different pieces' information, each of them becomes the Theme of other clauses afterwards.

The thematic structure can be used as a tool to analyse how the construction of a text and also to diagnose language weaknesses in writing product. There are three common problems of thematic development, those are the problem of the brand-new Theme, the problem of double Rheme, and the problem of the empty Rheme (Bloor \& Bloor, 1992). The problem of the brand-new Theme frequently occurs in writing product of inexperienced writer. This problem occurs when the new 
information is put on Theme position (Bloor \& Bloor, 1995). The next problem is the problem of double Rheme. It happens when a sentence has two Rhemes, one of which has never been mentioned previously (Bloor \& Bloor, 1992). The last is the problem of empty Rheme. It refers to the clause which fails to present new information in the Rheme position (Bloor \& Bloor, 1992).

In communication, people produce a text either spoken or written and convey a meaning. The text means any connected stretch of language that is doing job in some context (Halliday \& Hasan, 1985, p.10). A text is created when some words are put together which contains a meaning in order of communication. Creating a text requires us to make choices about the words used and how to put them together depends on the purpose and surrounding (context). The texts that were analysed in this study is recount texts.

Recount text is a text that retells past events in the order in which they happened (Anderson \& Anderson, 2003, p.48). This type of text demands the writer to arrange some events into chronological order. In recount text, learners must retell the sequence of events or experiences which they have ever got in the past (Nafisah \& Kurniawan, 2007, p.65). The generic structure of recount text consists of orientation, record of events, and re-orientation (Anderson \& Anderson, 2003, p.50). The orientation provides the background information of a text, such as who was involved, what happened, where the events took place, and when it happened. The record of events contains a series of events in a chronological sequence. The re-orientation consists of closure of events or the end of the story, usually stating personal comment of the writer to the story. Since recount text deals with sequence, the textual analysis of Theme-Rheme is suitable to be used. The textual meaning builds up sequences of discourse, organizing the discursive flow, and creating cohesion and continuity as it moves along (Halliday \& Matthiessen, 2014, pp.30-31).

There have been numerous studies on SFL in the field of textual meaning analysis. In this case, several researchers conducted studies on the textual meaning analysis of various kinds of texts. Some of the Indonesian researchers are interested in analyzing textual meaning on students' recount texts (Dewi \& Kurniawan, 2018; Febriyana, Sofwan \& Farida, 2018; Safitri \& Bahri, 2017; Yunita, 2018). Moreover, some studies from another country were focused on the types and problems of Theme-Rheme in EFL students' texts (Arunsirot, 2013; Ridha, 2014). Based on those studies, the study that is conducted in Indonesia which analyses the problems of thematic development is considered as the limited study.

In short, the Theme is essential to determine the point of departure in a text. The development of the Theme-Rheme is also essential because it shows the flow of information to maintain the cohesiveness of a text. Meanwhile, in constructing a text, EFL students do not pay attention on the thematic structures and thematic development, so it leads them to produce the problem. Undertaking the opportunity that there are still limited studies in Indonesia which analyses the problems of thematic development, this study is conducted in order to explain how the thematic structures and thematic development patterns of recount texts written by the fourth semester students of English Department Universitas Negeri Semarang is realized. Further, this study also tries to uncover the problems of thematic development in recount texts written by the fourth semester students of English Department Universitas Negeri Semarang in the academic year 2018/2019.

\section{METHODS}

This study investigates how the thematic structure, thematic development pattern, and the problems of thematic development that are found in students' recount texts. Therefore, the qualitative approach was used to figure out the realization of the meaning. The object of this study is students' recount texts, so the text analysis is employed.

The researcher collected the data from the Genre-Based Writing course of English Education Programme which consists of five classes. The researcher only took two best texts of each class based on the lecturers' selection, so there were ten texts. The best text is chosen because of this study aims to figure out the real problems that students' face in terms of textual meaning.

In analysing text, there are three level of analysis: the text as a whole, the sentence level, and the word or phrase level (Huckin, 1997, pp.81-84). The sentence level is chosen as the unit of analysis in this current study.

Before analysing the data, the researcher read the texts and identifying clauses which representing textual meaning. After that, breaking down the texts into clauses. Then, the clauses were numbered and analysed into three steps: analyse the thematic structures, analyse the thematic development patterns, and analyse the problems of thematic development. First, the data were given 
codes based on the categories of Theme elements. There are three elements of Theme: ideational/topical, interpersonal, and textual (Halliday \& Matthiessen, 2014, p.107). After the thematic structures are analysed, the next step is identified the thematic development patterns. There are three patterns: constant Theme/reiteration pattern, zigzag/linear pattern, and multiple-Rheme pattern (Eggins, 2004, pp.324-325). The thematic structures analysis is used to figure out the point of departure of each clause whereas the thematic development patterns analysis is used to see the flow of information in the texts. The last step is investigating the problems of thematic development in students' recount texts. There are three common problems of thematic development: the problem of the brand-new Theme, the problem of double Rheme, and the problem of empty Rheme (Bloor \& Bloor, 1992).

After analysing the texts, the researcher presented the results by using tables. Then, the results were put into the discussion part in order to discuss and review the meaning realized in students' recount texts. After that, the researcher drew the conclusion of the results. In order to know the validity of the data in qualitative research, the triangulation technique is employed. The type of triangulation technique that is chosen is investigator triangulation as an alternative observation from different expert of textual meaning.

\section{FINDINGS AND DISCUSSION}

This study investigated the textual meaning of recount texts written by the fourth semester students of English Department Universitas Negeri Semarang in the academic year 2018/2019. There were ten best texts taken from Genre-Based Writing course of English Education Programme. The findings of this study were derived from the Theme-Rheme system of each clause. There were three kinds of analysis: the thematic structures analysis, the thematic development patterns analysis, and the problems of thematic development analysis. The thematic structures were analysed to figure out the types of Theme that is used by students in order to show the point of departure of the message in each clause. The thematic development pattern analysis is used to see the flow of information in students' recount texts. The problems of thematic development analysis is used to uncover the common problems of misusing Theme-Rheme in students' recount texts that indicates the students' writing ability.

\section{Thematic Structures Realized in Students' Recount Texts}

The thematic structure plays an important role in organizing the message and enhances connectivity between ideas in the text (Halliday \& Matthiessen, 2014). Theme is divided into two: simple Theme and multiple Theme. Simple Theme is a Theme which contains the experiential elements either participant, circumstance, or process which refers to topical Theme (Halliday \& Matthiessen, 2014, p.105). Furthermore, the other elements may occur before the topical Theme, either textual, interpersonal, or both of them. The table below shows the thematic structures in students' recount texts.

Table 1. Summary Findings of Thematic Structures

\begin{tabular}{|c|c|c|c|c|c|c|c|c|c|c|}
\hline \multirow[t]{2}{*}{$\begin{array}{c}\text { Recount } \\
\text { Texts }\end{array}$} & \multicolumn{2}{|c|}{$\begin{array}{c}\text { Ideational/ } \\
\text { Topical }\end{array}$} & \multicolumn{2}{|c|}{$\begin{array}{c}\text { Textual } \\
\text { (Textual- } \\
\text { Topical) }\end{array}$} & \multicolumn{2}{|c|}{$\begin{array}{c}\text { Interpersonal } \\
\text { (Interpersonal- } \\
\text { Topical) }\end{array}$} & \multicolumn{2}{|c|}{$\begin{array}{c}\text { Textual- } \\
\text { Interperson } \\
\text { al-Topical }\end{array}$} & \multicolumn{2}{|c|}{ SUM } \\
\hline & $\sum$ & $\%$ & $\sum$ & $\%$ & $\sum$ & $\%$ & $\sum$ & $\%$ & $\sum$ & $\%$ \\
\hline Text 1 & 18 & 4.8 & 17 & 4.5 & 0 & 0.0 & 1 & 0.3 & 36 & 9.6 \\
\hline Text 2 & 8 & 2.1 & 2 & 0.5 & 0 & 0.0 & 0 & 0.0 & 10 & 2.7 \\
\hline Text 3 & 26 & 6.9 & 14 & 3.7 & 0 & 0.0 & 0 & 0.0 & 40 & 10.7 \\
\hline Text 4 & 30 & 8.0 & 17 & 4.5 & 0 & 0.0 & 1 & 0.3 & 48 & 12.8 \\
\hline Text 5 & 18 & 4.8 & 18 & 4.8 & 0 & 0.0 & 0 & 0.0 & 36 & 9.6 \\
\hline Text 6 & 15 & 4.0 & 20 & 5.3 & 0 & 0.0 & 0 & 0.0 & 35 & 9.3 \\
\hline Text 7 & 25 & 6.7 & 22 & 5.9 & 5 & 1.3 & 1 & 0.3 & 53 & 14.1 \\
\hline Text 8 & 28 & 7.5 & 31 & 8.3 & 1 & 0.3 & 0 & 0.0 & 60 & 16.0 \\
\hline Text 9 & 26 & 6.9 & 15 & 4.0 & 0 & 0.0 & 0 & 0.0 & 41 & 10.9 \\
\hline Text 10 & 7 & 1.9 & 7 & 1.9 & 2 & 0.5 & 0 & 0.0 & 16 & 4.3 \\
\hline SUM & 201 & 53.6 & 163 & 43.4 & 8 & 2.1 & 3 & 0.9 & 375 & 100.0 \\
\hline
\end{tabular}


As showed in the table 1, the ideational/topical Theme is frequently used by students (53.6\%) followed by the textual Theme (43.4\%), interpersonal Theme $(2.1 \%)$, and the rarest used is textualinterpersonal-topical Theme (0.9\%).

\section{Thematic Development Patterns in Students' Recount Texts}

There are three main patterns of thematic development namely constant Theme/reiteration pattern, zigzag/linear pattern, and multiple-Rheme pattern (Eggins, 2004, pp.324-325). The table below shows the thematic development patterns in students' recount texts.

Table 2. Summary Findings of Thematic Development Patterns

\begin{tabular}{|c|c|c|c|c|c|c|c|c|}
\hline \multirow[t]{2}{*}{$\begin{array}{c}\text { Recount } \\
\text { Texts }\end{array}$} & \multicolumn{2}{|c|}{$\begin{array}{l}\text { Constant } \\
\text { Theme } \\
\text { Pattern }\end{array}$} & \multicolumn{2}{|c|}{$\begin{array}{l}\text { Zigzag } \\
\text { Theme } \\
\text { Pattern }\end{array}$} & \multicolumn{2}{|c|}{$\begin{array}{l}\text { Multiple - } \\
\text { Rheme } \\
\text { Pattern }\end{array}$} & \multicolumn{2}{|c|}{ SUM } \\
\hline & $\sum$ & $\%$ & $\sum$ & $\%$ & $\sum$ & $\%$ & $\sum$ & $\%$ \\
\hline Text 1 & 6 & 2.7 & 10 & 4.5 & 1 & 0.4 & 17 & 7.6 \\
\hline Text 2 & 1 & 0.4 & 2 & 0.9 & 0 & 0.0 & 3 & 1.3 \\
\hline Text 3 & 14 & 6.3 & 11 & 4,9 & 0 & 0.0 & 25 & 11.2 \\
\hline Text 4 & 9 & 4.0 & 13 & 5.8 & 2 & 0.9 & 24 & 10.7 \\
\hline Text 5 & 11 & 4.9 & 12 & 5.4 & 0 & 0.0 & 23 & 10.3 \\
\hline Text 6 & 16 & 7.1 & 2 & 0.9 & 1 & 0.4 & 19 & 8.5 \\
\hline Text 7 & 20 & 8.9 & 16 & 7.1 & 2 & 0.9 & 38 & 17.0 \\
\hline Text 8 & 22 & 9.8 & 14 & 6.3 & 4 & 1.8 & 40 & 17.9 \\
\hline Text 9 & 18 & 8.0 & 8 & 3.6 & 0 & 0.0 & 26 & 11.6 \\
\hline Text 10 & 7 & 3.1 & 2 & 0.9 & 0 & 0.0 & 9 & 4.0 \\
\hline SUM & 124 & 55.2 & 90 & 40.3 & 10 & 4.4 & 224 & 100.0 \\
\hline
\end{tabular}

As showed in the table 2 , the constant Theme pattern is mostly used by students $(55.2 \%)$ followed by the zigzag pattern $(40.3 \%)$, and the rarest pattern that is used by students is multipleRheme pattern (4.4\%).

\section{The Problems of Thematic Development in Students' Recount Texts}

There are three common problems of thematic development resulting from the misuse of ThemeRheme, those are the problem of the brand-new Theme, the problem of double Rheme, and the problem of the empty Rheme (Bloor \& Bloor, 1992).

\section{The Problems of the Brand-New Theme}

The new Theme is introduced in the text causing a lack of organizational skill in the writing. Here are some examples of the brand-new Theme found in students' recount texts:

(a) All of the students, except a boy who was my rival in the subject, agreed that it was the right answer.

(b) Then, the time that had been anticipated finally came, the teacher's justification.

(c) When I was looking for boarding house, unexpectedly I met my best friend, ...

The sentences (a) and (b) belongs to the problems of the brand-new Theme since the text is focused on ' $I$ ' and 'the teacher', so the Theme 'All of the students, except a boy who was my rival in the subject' and 'Then, the time that had been anticipated' include into new Themes that have been introduced. Meanwhile, in the clause (c), the Theme 'When I was looking for boarding house' introduced as a new Theme since the text is focused on ' $I$ '.

\section{The Problems of Double Rheme}

This problem occurs when the sentence has two Rhemes with one of the Rhemes is not mentioned previously (Bloor \& Bloor, 1992). Below are some examples of the double Rheme found in students' recount texts:

(a) At that time men and woman workers rallied demanding justice for workers...

(b) ... so that good working condition and working hours became reasonable not too long.

(c) At that time my friend and I were practicing football with our teacher. 
Each of the example above contains two Rheme which is the second Rheme is not mentioned previously.

\section{The Problems of Empty Rheme}

The empty Rheme refers to the clause which fails to present new information in the Rheme position (Bloor \& Bloor, 1992). There is an example of the empty Rheme found in students' recount texts:

(a) After considered a lot of things which course I would choose.

The example above is a sentence that considered into dependent clause and does not have independent clause until the full stop, so it is considered as a problem.

\section{Discussion}

This part presents the interpretation of the findings compared to the previous studies and the theories used.

\section{Thematic Structures Realized in Students' Recount Texts}

Theme is the point of departure while the Rheme is the part which the Theme developed (Halliday and Matthiessen, 2014, p.89). Based on the amount of the Theme in a clause, Theme can be divided into two categories: simple Theme and multiple Theme. Simple Theme is a Theme which contains the experiential elements, either participant, circumstance, or process which refers to topical Theme (Halliday \& Matthiessen, 2014, p.105). Multiple Theme is a Theme which contains more than one element, the other elements either textual, interpersonal, or both of them preceding before the topical Theme (Halliday \& Matthiessen, 2014, p.107).

The findings show that students tend to use simple Theme than the multiple Theme (see table 1). This finding in contrast with Arunsirot's (2013) study. This could be happened due to the fact that the object in Arunsirot's study has different genre with this current study. Arunsirot analysed argumentative texts while this study analysed recount texts. In argumentative texts, students are attempted to persuade the readers by adding textual Theme and interpersonal Theme before the topical Theme in order to link logical steps of their arguments. Whereas in recount texts, students do not need to persuade the readers, they only tell the readers about the past experiences through the series of events, so they often used circumstance of time and place which belong to topical Theme. Furthermore, the occurrence of simple Theme mostly found on descriptive and recount text (Yunita, 2018).

It is not surprising if simple Theme which contains the topical Theme became the most frequently used Theme in students' recount texts. It is because of each clause contains one topical Theme, in turn, is one nominal group, adverbial group, or prepositional phrase (Halliday \& Matthiessen, 2014, p.92). Topical Theme is divided into marked and unmarked. Unmarked topical Theme is more dominant than the marked one. It is found that the use of nominal group occurs in great quantities than the other groups. Almost all of students' recount texts use pronoun ' $T$ ' in the beginning of the clause, for example I'm very excited and enthusiastic.; I went to Kediri by train.; Finally, I held back my pee.; I felt very embarrassed...; etc. The students emphasized on the nominal group as the point of delivering the message since it is about their personal experience. It is also easier to begin a clause using nominal group than adverbial, complement, or prepositional phrase. It is in line with the findings of the study conducted by Febriyana (2017) since the genre of the object of the study is the same. She also assumed that it is an ordinary case for those who belong to beginner writers. Based on the similarity of the tendency of the chosen component in the beginning of a clause, it can be said that as ' $a$ writer', the students are considered to the beginner writers. The marked Themes are chosen by skilful writers or speakers to add the coherence and emphasis their texts (Eggins's, 2004, p.320).

The next type of Theme realized in students' recount texts is textual Theme (see table 1). Based on the findings, the most used element is conjunctions. For example, ... and the ritual was held on May 1.; ... and sometimes she was crying.; ... because I had not been accepted...; etc. The use of conjunctions is the easiest way to link one clause to another than the other elements. It is not surprising because the function of conjunction is to link clauses in order to maintain the coherent and cohesiveness of a text. It is in line with the study conducted by Arimafrida (2016) although it has different genre with this object of the study. Students tend to choose conjunctions than continuatives or conjunctive adjunct. It indicates that the students are aware of the important role of the conjunctions and have been trying to maintain the coherent and cohesiveness of their text. In 
contrast with conjunctions, there is only one continuative found in students' recount texts since it is associated with the spoken features. It happens because continuative element is mostly used in spoken text as a set of words which signal a move in the discourse: a response, in dialogue, or a new move to the next point if the same speaker is continuing (Halliday \& Matthiessen, 2014, p.107).

The last and the rarest type of Theme found on students' recount texts is interpersonal Theme (see table 1). Students tend to use modal adjunct than the other elements. Some examples of the used of modal adjuncts in interpersonal Theme such as... unfortunately, that is not apply...; ... unexpectedly I met my best friend, ...; ... maybe at 8 p.m. we decided to leave...; etc. The rare used of the interpersonal Theme in students' recount texts is acceptable since it commonly occurs in the conversation (Eggins, 2004). It happens because the interpersonal Theme often found in spoken texts for students to join and sustain their interaction (Butt et al., 2000). And also confirms by Halliday \& Matthiessen's (2004, p.84), statement as follows.

"If there is a Vocative in the clause, or a modal or comment Adjunct, it is quite likely to be thematic: these items are characteristic of dialogue, in which the speaker may be calling the attention of the listener, or else expressing his or her own angle on the matter in hand, whether probable, desirable, and so on, and hence they tend to be brought in as key signature to the particular move in the exchange - in other words, as Theme of the clause."

From those statements, it can be concluded that interpersonal Theme tends to be used in spoken text. Meanwhile, the conversation or spoken interaction is rarely used in the recount texts, thus it may lead the background of infrequent number of occurrences of the interpersonal Theme in students' recount texts.

The analysis of textual meaning clause by clause gained by an insight that the students made clear to the reader their underlying concerns and how they developed it. The Theme-Rheme analysis showed that the students presented their concerns of their story and provided the details by presenting the definition, giving example, stating the value, and elaborating the sequence of event. Based on the tendency of the chosen component in the beginning of a clause, the students are considered to the beginner writers although they have been in the fourth semester college students (see Eggins, 2004, p. 320).

\section{Thematic Development Patterns in Students' Recount Texts}

After the Thematic structure of each clause is analysed, it is needed to know how Theme of each clause related each other in order to be cohesive and coherent. Then the analysis of thematic development employed to know the flow of information in which how meanings are packaged in order to make it easier to understand (Martin \& Rose, 2007, p. 187). An analysis of the thematic development in each clause is important since it is particularly sensitive to the staging of genre (Martin \& Rose, 2007, p. 198). There are three patterns of thematic development: constant Theme pattern; zig-zag pattern; and multiple-Rheme pattern (Eggins, 2004, pp.324-325).

Based on the findings, the constant Theme pattern became the most used pattern followed by zig-zag pattern and the last is multiple-Rheme pattern (see table 2). It happens because 'one basic way to keep a text focused (i.e. cohesive) is simply to re-iterate an element' (Eggins, 2004, p. 324). Constant Theme pattern is considered to be the easiest way to provide the text with a clear focus. This can be examined in the following examples.

\begin{tabular}{|c|c|}
\hline Theme & Rheme \\
\hline Since then, $I \longrightarrow$ & had been traumatized by that moment \\
\hline$\longrightarrow$ & didn't want to answer teacher's question anymore \\
\hline because & was afraid \\
\hline in case & would have been yelled again \\
\hline$\longrightarrow$ & gave the wrong answer. \\
\hline
\end{tabular}

Although begin with different conjunctions, the point of departure is still same in which the repetition of the topical Theme ' $T$ '. The repetition of the subject ' $T$ ' represents that the focus of the 
message is about ' $I$ '. Since the text contains reiteration of the element, it is considered to have the constant-Theme pattern in the text development.

\begin{tabular}{|ll|l|}
\hline \multicolumn{2}{|c|}{ Theme } & \multicolumn{1}{c|}{ Rheme } \\
\hline We & $\longrightarrow$ & continue our trip by visiting zoo near there. \\
\hline and (we) & $\longrightarrow$ & walked around \\
\hline and (we) & $\longrightarrow$ & saw various kinds of animal. \\
\hline
\end{tabular}

All of the clauses above use pronoun ' $w e$ ' as the topical Theme. They reiterate the point of the departure in order to keep the text focused. The text is also containing the repetition of the conjunction 'and' to connect a clause with the previous clause in order to maintain the coherence of the text. Even though the subject ' $w e$ ' after the conjunctions was ellipsis, the point of departure is still the same. Thus, the focused message of the text is about ' $w e$ '.

The next pattern appears in students' recount texts is zig-zag pattern. The zig-zag pattern reached cohesion of the text by building on newly introduced information (Eggins, 2004, p.325). In other words, the Rheme of the previous clause is taken into the Theme of the next clause. From the findings, the writers used zig-zag patterns as the second way to make new clauses besides constant theme pattern (see table 2). Here is an example of zigzag pattern found in students' recount texts.

\begin{tabular}{|l|l|}
\hline \multicolumn{2}{|c|}{ Theme } \\
\hline First,
\end{tabular}

From the text above, the Rheme of the first clause 'Bukit Pananjakan' is elaborated as a Theme in the fourth clause. It is the same with the second clause and the sixth clause.

The rarest pattern that is students used is multiple-Rheme pattern. There are only 2 patterns appear among 10 texts. The pattern belongs to multiple-Rheme pattern when the Rheme of a clause is elaborated into some Themes for the next clauses. Here is one of the examples.

\begin{tabular}{|l|l|}
\hline \multicolumn{1}{|c|}{ Theme } & Rheme \\
\hline There & are three points that we would visit. \\
\hline First, & "Bukit Telletubies". \\
\hline and the last $\longrightarrow$ & "Bumuk Pasir Berbisik" \\
\hline
\end{tabular}

This part of the text contains the multiple-Rheme pattern in which the Rheme 'three points' in the first clause is elaborated in the Theme of the next clauses as the points which are mentioned.

Each of text-types tends to deal with the particular types of thematic development, these are re-iteration (constant), zigzag (linier), and multiple (split). The constant continuous Themes tend to be used mostly in such texts as narratives, recounts, and reports while simple linier pattern or crossreferential Thematic Theme mostly used in descriptive and reports (Rosa, 2013, p.223). Therefore, re-iteration (constant) pattern is the most frequent pattern used in the texts since recount text is a text-type which mostly uses constant pattern as the Thematic development. Moreover, it is also 
found the combination of re-iteration, zigzag and multiple patterns in students' recount texts as it is uncommon to have only one pattern in a whole text. There is always a possibility to use all types of thematic development pattern in a particular type of text, but the text must have one dominant type of thematic development pattern (Rosa, 2013).

\section{The Problems of Thematic Development in Students' Recount Texts}

Thematic structure plays an important role in organizing the message and enhances connectivity between ideas in the text (Halliday, 2014). It is used as a tool to analyse how the texts are constructed and to diagnose language weaknesses in the student's writing product. There are three common problems of thematic development resulting from the misuse of Theme-Rheme, those are the problem of the brand-new Theme, the problem of double Rheme, and the problem of the empty Rheme (Bloor \& Bloor, 1992). Through those categories, it is found several problems in students' recount texts.

Several problems in terms of the brand-new Theme were found in students' recount texts. In this case, the new Theme is introduced in the text causing a lack of organizational skill in the writing. For example, the writer talks about her embarrassing experience in English class in text 6. The Themes of almost all sentences in the body paragraph refers to the writer by using the pronoun ' $T$ ' and 'the teacher', except the seventh and ninth sentences. In this case, the Themes 'All of the students, except a boy who was my rival in the subject' and 'Then, the time that had been anticipated' were introduced in the text. Here, these Themes are first mentioned among the text. It happens because the students are considered as the beginner writer as mentioned in the previous part of discussion. The occurrence of this problem indicates that the writer, in case student, showing inability in developing a coherence text. It can be said that the problem of a brand-new Theme occurs in the work of inexperienced writers who put new information in the Theme position (Bloor \& Bloor, 1995).

The next problem occurs in students' recount text is the problem of double Rheme. This problem occurs when the sentence has two Rhemes with one of the Rhemes is not mentioned previously (Bloor \& Bloor, 1992). This problem causing confusion since the Rheme that is mentioned previously will seem as not related to the remains. In the analysis, it is found that there are three clauses having this problem. One of them is '... so that good working condition and working hours became reasonable not too long.'. It can be seen that the Rhemes are 'good working condition became reasonable not too long' and 'working hours became reasonable not too long'. The occurrence of the second Rheme will make the previous Rheme seem as not related to the remains of the Rheme (became reasonable not too long). This problem did not occur in the study that was conducted by Arunsirot (2013) and Ridha (2014). It may happen because the genre of the analysed texts is different.

The empty Rheme refers to the clause which fails to present new information in the Rheme position (Bloor \& Bloor, 1992). In other word, the Rheme is not further developed. It only found one sentence having this problem. The sentence is 'After considered a lot of things which course I would choose.'. This sentence is considered into dependent clause and does not have independent clause until the full stop. The sentence contains a Theme, but does not have Rheme, that is called empty Rheme. It causes confusion for the readers because the writer of the text does not mention what happens after the course is chosen. This problem occurs in the study conducted by Arunsirot (2013) and Ridha (2014), but in different case.

\section{CONCLUSION}

This study aimed to figure out the thematic structure, thematic development pattern, and the problems of thematic development found in recount texts written by the fourth semester students of English Department Universitas Negeri Semarang. The result of the thematic structures show that the unmarked topical Theme is frequently used than the marked one in terms of topical Theme, the conjunctions became the mostly used element in textual Theme, and the modal adjuncts became the frequently used constituent in interpersonal Theme. In the case of thematic development patterns, the Theme re-iteration (constant Theme pattern) became the mostly used pattern since the function is to keep the text focused followed by the zigzag pattern, and the last is multiple-Rheme pattern. It has been found three problems of thematic development in students' recount texts, there are the problem of the brand-new Theme, the problem of double Rheme, and the problem of empty Rheme. The results of this study indicate that the students belong to beginner (inexperienced) writer. Any 
analysis of SFL needs more linguistic evidence to make judgement rather than intuition, thus research on different kind of text may reveal additional findings.

\section{REFERENCES}

Anderson, K. \& Anderson, M. (2003). Text Types in English (2nd ed.). Australia: Macmillan ed.

Arimafrida, T. (2016). Textual meanings realized in students' narrative texts (a case of the eleventh grade students at Senior High School 1 Jepara in academic year 2014/2015) (Unpublished final project). Universitas Negeri Semarang, Semarang, Indonesia.

Arunsirot, S. (2013). An analysis of textual metafunction in Thai EFL students' writing. NovitasROYAL (Research on Youth and Language), 7(2), pp.160-174.

Bloor, M. \& Bloor, T. (1992). Given and new information in the thematic organization of text: An application to the teaching of academic writing. Occasional Papers in Systemic Linguistics, 6, pp.3344.

Bloor, M. \& Bloor, T. (1995). The Functional Analysis of English: A Hallidayan Approach. London: Arnold.

Butt, D., Fahey, R., Feez, S., Spinks, S., \& Yallop, C. (2000). Using Functional Grammar: An Explorer's Guide (2 ${ }^{\text {nd }} e$ d.). Sydney: National Centre for English Language Teaching and Research.

Dewi, R. K. S. \& Kurniawan, E. (2018). Seeing recount from systemic functional linguistic perspective: sine qua non attributes. RETORIKA: Jurnal Ilmu Bahasa, 4(1), pp.43-52. https://doi.org/10.22225/jr.4.1.464.43-52

Eggins, S. (2004). An Introduction to Systemic Functional Linguistics (2 ${ }^{\text {nd }}$ ed.). London: Continuum International Publishing Group.

Febriyana, A., Sofwan, A., \& Farida, A. N. (2018). An analysis of textual meaning on students' writing of recount texts. Journal of Englosh Language Teaching, 7(2), pp.54-62.

Halliday, M. A. K. \& Hasan, R. (1985). Language, Context, and Text: Aspect of Language in SocialSemiotic Perspective. Victoria: Deakin University Press.

Halliday, M. A. K. \& Matthiesen, C. M. I. M. (2004). An Introduction to Functional Grammar (3 ${ }^{\text {rd }} e d$.). Great Britain: Hodder Arnold.

Halliday, M. A. K. \& Matthiesen, C. M. I. M. (2014). An Introduction to Functional Grammar (4th ed.). London: Routledge Taylor \& Francis Group.

Huckin, T. N. (1997). "Critical Discourse Analysis", in Miller, Tom (ed). Functional Approaches to Written Text: Classroom Applications. Washington DC: United States Information Agency, pp.7892.

Martin, J. R., Matthiessen, C. M. I. M., \& Painter, C. (1997). Working with Functional Grammar. London: Arnold.

Martin, J. R. \& Rose, D. (2007). Working with Discourse: Meaning Beyond the Clause (2nd ed). New York: Continuum.

Nafisah, N. \& Kurniawan, E. (2007). Writing English for General Communication. Bandung: UPI PRESS.

Ridha, N. S. A. (2014). Theme and rheme: types and problems in EFL university students' written texts. pp. 93-114.

Rosa, R. N. (2013). Thematic progression as a model used to keep cohesion in writing an exposition text. Proceedings of ISELT FBS Universitas Negeri Padang, 1, pp.220-228.

Safitri, I. \& Bahri, S. (2017). Thematic progression on students' recount texts. Journal of English Language Teaching, 6(1), pp. 69-82. 